\title{
Project-based learning as an element of the university innovation ecosystem
}

\author{
Yulia Khodkovskaya ${ }^{1, *}$, Olga Malykh² \\ ${ }^{1}$ Ufa State Petroleum Technological University, 1 Kosmonavtov st., Ufa, 450076, Russian Federation
}

\begin{abstract}
The article presents an analysis of the development problems of project-based learning technology in Russian universities, which can make a significant contribution to achieving the goal of academic leadership. The issues of the formation of the competencies of a university graduate in the context of project-based learning are considered. It is shown that project-based learning should be included in a multifactor educational environment - the innovative ecosystem of the university. The relationship between the elements of the university's innovation ecosystem, such as education, individual learning path, project-based learning, digital content, polylingual content, non-formal education, partnership programs, supervising, mentoring, design and interdisciplinarity, has been determined. The article substantiates the criteria for the effectiveness of project-based learning, and also offers options for the formation of the innovative ecosystem of the university, as a new trend in the Russian educational environment, which allows students to be involved in research and project work.
\end{abstract}

\section{Introduction}

It has been proven many times in theory and practice that education is a key area of human economic activity. Over the past three decades, many problems associated with it have accumulated in Russia: organizational, financial, social, economic, etc. However, it cannot be said that society and the state do not care about these issues. So, in the 2020s, the implementation of the "5100 " program was completed, with the goal of entering the leading Russian universities to international ratings. In 2021, the program of strategic academic leadership "PRIORITET-2030" was launched, the result of which the government of the Russian Federation sees "training of personnel for priority areas of scientific and technological development of the Russian Federation, economic and social sectors, the development and implementation of breakthrough research and development, new creative and social and humanitarian projects, as well as the introduction of high technologies into the economy and social sphere".

There is a large amount of research in the field of education, among which, in the context of this article, it is of interest to analyze the possibilities of an interdisciplinary approach to project-based learning, which consistently connects such components as creative and critical thinking, accumulated experience, thus facilitating innovation [1]. An additional advantage of this approach is the professional stability of university graduates and their ability to work effectively in a team [2]. At the same time, many researchers note the complexity of organizing project-based learning, since not in all countries of the world it is possible to create such an innovative ecosystem today [3]. At the same time, it is important to understand the economic possibilities of the government in creating and supporting innovations in universities [4, 5]. Such elements of the university innovation ecosystem as digitalization of education and the involvement of participants in the educational process to the discussion of integrated curricula [6, 7], technology transfer algorithms and the commercialization of university research [8], as well as critical criteria for the success of business incubators, growth accelerators [9] are also actively being discussed.

\section{RESULTS}

A critical review of approaches to the definition and essence of project-based learning in Russian and foreign universities revealed its advantages in training university graduates, which is manifested in the flexibility of the educational technologies used, combining traditional forms with digital ones. It should be noted that many publications devoted to project-based learning in universities focus on the quality of training of specialists, activation of their zero gravity thinking, and, as a consequence, the formation and development of universal competencies of students in a digital educational environment.

Analysis of the results of project-based learning in leading universities in Russia and Europe showed that its application stimulates the research and development and educational activities of students, and the use of modern information and communication technologies in projectbased learning significantly increases the effectiveness of training. In the surveyed universities in Western

*Corresponding author: khodkovskiy@bk.ru 
Europe (Lancaster University Management School (UK), European School of Management and Technology (Germany), The University of Manchester (UK), Turku University of Applied Sciences (Finland), etc.) in the process of project-based learning students acquire interdisciplinary knowledge that determines the training of digital personnel. Thus, it can be concluded that in most European countries university education contains project-based learning as an indispensable component.

The results of studies of relevant practices of Russian universities (Moscow School of Management "Skolkovo", South Ural State University, Moscow Higher School of Social and Economic Sciences, etc.) made it possible to establish that the fundamental training of university students is based on the harmonious application of global educational trends, taking into account the national educational identity. In addition, the quality of university graduates is ensured through the integration of educational, research, economic and social processes. Moreover, this conclusion is the same for both Russian and foreign universities.

The competence of graduates in the modern labor market ensures their competitiveness. All competencies, taking into account the pace of development of scientific and technological progress, the changing demands of employers for the quality of education become obsolete, lose their importance, which manifests itself through the "half-life" of competencies, increasing the importance of improving the educational programs offered by universities.

Project-based learning contributes to the development of new, digital-economy-oriented competencies of graduates.

It should be noted that the competencies of university graduates in the innovation ecosystem of the university are formed as a synergistic result of "student consumption" of educational, research and development and business products offered by the university (Fig.1).

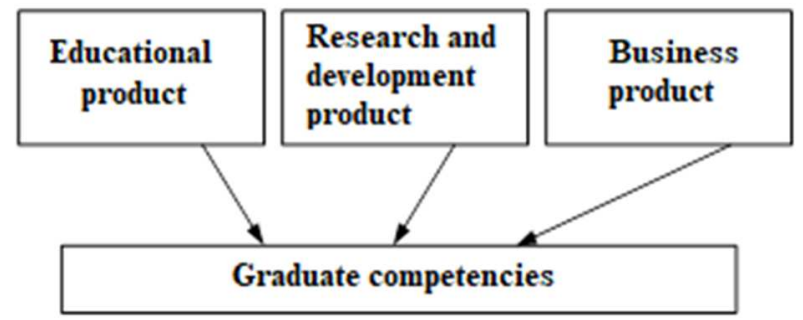

Fig. 1. Project-based learning: graduate competencies

For university graduates, supra-professional competencies aimed at developing social responsibility, safety management, and high-quality implementation of interaction interfaces are also important.

However, a comparison of the degree of involvement of domestic universities in the implementation of project-based learning technology leads to the need to solve the problem of taking into account the "multifactorial nature" of the existing educational environment when building the professional personal trajectory of students.

Despite the fact that the sectoral focus of Russian universities is very wide, the focus on consolidation, unification of universities, the creation of national educational and research and development centers, allows us to identify modern universities as global centers for the training of a polytechnic profile and science. Thus, the need for possessing universal competencies that increase the competitiveness of university graduates is actualized. In this aspect, projectbased learning is an important tool of modern university education, an element of the university's innovation ecosystem.

Table 1. Effectiveness criteria of project-based learning

\begin{tabular}{|c|c|}
\hline Consistency & $\begin{array}{l}\text { Mastering knowledge, skills } \\
\text { and abilities of professional } \\
\text { activity based on the principle } \\
\text { of "education throughout life": } \\
\text { from theoretical foundations to } \\
\text { improving the cognitive process } \\
\text { and the development of } \\
\text { universal competencies. }\end{array}$ \\
\hline Agility & $\begin{array}{l}\text { It manifests itself through } \\
\text { changes in the multilevel } \\
\text { training of university graduates, } \\
\text { forms of advanced training, new } \\
\text { specialties and specializations } \\
\text { that meet the social and } \\
\text { economic conditions of the } \\
\text { development of society. }\end{array}$ \\
\hline Polytechnology & $\begin{array}{l}\text { Associated with project } \\
\text { activities as part of the } \\
\text { formation of a digital ecosystem } \\
\text { of universities. It involves the } \\
\text { use of a wide range of modern } \\
\text { tools and teaching methods in } \\
\text { the communication and } \\
\text { information space. }\end{array}$ \\
\hline Adaptability & $\begin{array}{l}\text { Training of digital personnel } \\
\text { based on project-based learning, } \\
\text { taking into account the requests } \\
\text { of stakeholders along the chain } \\
\text { "science-university education- } \\
\text { business community-APE". }\end{array}$ \\
\hline Transparency & $\begin{array}{l}\text { The openness and accessibility } \\
\text { of project-based learning } \\
\text { determine the opportunities to } \\
\text { build a professional personal } \\
\text { trajectory of a student in the } \\
\text { organization of university } \\
\text { education. }\end{array}$ \\
\hline Flexibility & $\begin{array}{l}\text { The advantage of project-based } \\
\text { learning is the flexibility of the } \\
\text { educational technologies used } \\
\text { combining traditional forms } \\
\text { with digital ones. }\end{array}$ \\
\hline
\end{tabular}

The peculiarities of the formation and development of the university education system in Russia have significantly changed the key principles, criteria for the effectiveness of higher education, focusing on the needs of the modern labor market. Such factors as the growth rate of digitalization of the economy, transfer of 
knowledge and technologies, integration processes, international cooperation in the field of education, a number of researchers are said to be the most significant for improving the system of university education.

Depending on the combination of factors and their significance, the university environment differs from mono- to polyuniversities, including additional professional education (APE). At the same time, there is a widespread opinion about the importance of vocational education, mastering practical skills, which actualizes the implementation of "double diploma" programs, a variety of specializations in the curricula of training programs for bachelors, specialists, masters, simultaneous mastering of the profession at production sites.

The effectiveness of university education in Russia is associated with project-based learning focused on the creative self-realization of students, increasing their competitiveness in the context of digitalization of business and society through the development of intellectual abilities, their creative application in the digital educational environment. Therefore, it becomes necessary to use project-based learning along the chain "science - university education - business community additional professional education (APE)". The criteria for efficiency in this case can be considered consistency, dynamism, polytechnology, adaptability, transparency and flexibility (Tab. 1).

The presented criteria in general make it possible to assess the effectiveness of project-based learning, and, therefore, to identify it as an innovative approach to acquiring knowledge, mastering modern methods and skills.

Project-based learning as an element of the university's innovation ecosystem is implemented through a variety of communication links, both internal and external (Fig. 2). In this regard, the so-called "spillover effects" arise, taking into account the interactions of all interested parties along the chain "science - university education - business community additional professional education (APE)". Effects of this kind can spread both within one country and in international cooperation.

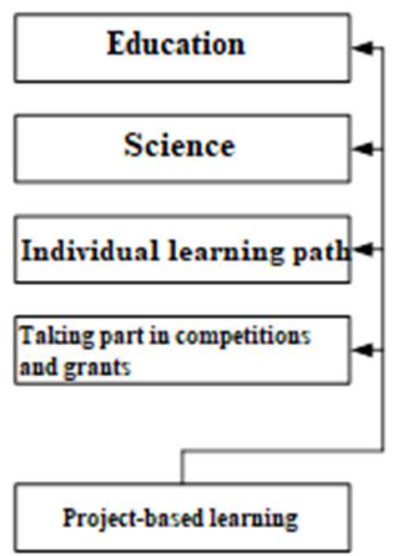

Fig. 2. Project-based learning as an element of the university innovation ecosystem

\section{DISCUSSION}

Many authors note that in a competitive market, the redistribution of economic resources occurs in favor of the ecosystem of the university that has the potential for growth, infrastructure resources that provide unhindered integration and interaction of material, financial, labor and information flows that form complex multi-level logistics chains [10], self-development and selforganization of all elements of the university innovation ecosystem.

The ecosystem of a modern university is a dynamically developing environment that creates opportunities for expanding educational, research activities, developing cooperation and partnerships both at the level of higher educational institutions and at the level of the business community.

The development of business cooperation and business partnerships in the university environment, for example, in the UK, Israel, Canada, Spain, Italy, South Korea, Finland, involves a significant revision and improvement of educational programs, taking into account a whole range of requirements for the quality of mastering universal competencies, fluency in technology digital modeling, management of complex technical or professional activities. In this aspect, digital learning is the university's tool that allows you to overcome the barriers to technology transfer, exchange effective methods, scale and replicate the results of scientific research in the business environment. In addition, project-based learning at the universities of aforementioned countries is actively developing due to the attraction of additional external funding, which means that research and development of universities are being introduced and adapted to the business community at an outstripping pace. Particularly popular are venture projects (in Russian practice, analogs are leadership projects, free projects), which allow you to quickly and easily use the resource capabilities of databases, cloud storages containing modern achievements of science and practice, solving applied problems of the business community.

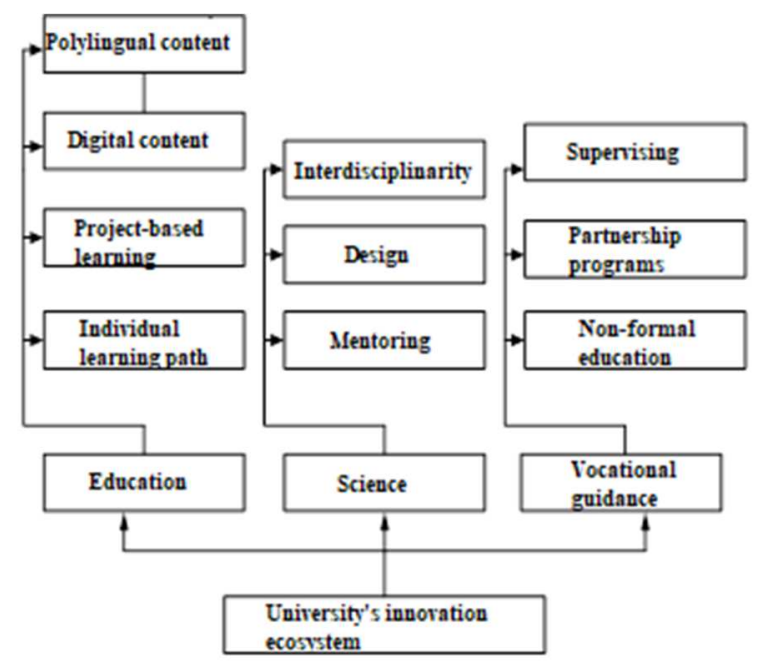

Fig. 3. Innovation ecosystem of the university 
One of the elements of the innovation ecosystem of the university is polylingual content, which includes multilingual teaching of students, the importance of which has significantly increased in recent years (Fig. 3). This was facilitated by the processes of globalization, internationalization, integration interaction, the development of a system of international network, distance education format, the adoption by Russia of the provisions of the Bologna Declaration on a single European space in higher education [11].

The university's multilingual content connects the educational environment with the business community, ensures the building of business communications, using both the native language and "international languages".

For project training, the priority of poly-lingual content is confirmed by the fact that advanced foreign schools for training project managers in modern universities teach in English, which is recognized as the corporate language of business communication. Consequently, it becomes possible to get acquainted with primary sources, interact with representatives of science and business from other countries using multilingual knowledge. In addition, the consequences of the COVID situation have accelerated the development of distance educational programs, online courses, the availability of which increases as users learn "international languages".

Digital content as an element of the university's innovation ecosystem is inseparable from project-based learning. The educational programs of most modern universities in the era of digital transformations rely on the active use of digital technologies that provide higher speed, accuracy of calculations, variability of research results, which is important in project-based learning and at the same time attractive for business.

Project learning in a modern university environment is inextricably linked by accumulators of analytical information such as Big data, HDD and SSD drives, cloud storage, which requires in-depth digital knowledge and skills. As the analysis of the practice of Russian universities shows that joint R\&D projects, on $\mathrm{QR}$ coding in recent years, which have become widespread in recent years, rely on digital decision-making models.

Also, in the innovation ecosystem of the university, an individual learning trajectory is important, its connection with project-based learning can be traced as a result of the development of critical thinking, creative, non-standard vision of solving a problem, searching for innovative ways to solve problems of science and business.

The advantage of project-based learning in building the individual trajectory of students is manifested in the fact that the formed information and communication space of universities makes it possible to choose a number of courses, taking into account the future professional activities of students (elective courses, workshops, free courses within the Student Academies, etc.). In addition, modern methods of cognition, online intensives, gamification, business trainings, master classes that develop new professional competencies in students are widely used in project-based learning.

Mentoring, design and interdisciplinarity are also elements of the university's innovation system. The importance of the above elements is explained by the fact that project-based learning is implemented along the chain "science - university education - business community - additional professional education (ADE)", increasing the importance of the elements describing the block "science" in the university ecosystem.

Mentoring is perceived in the innovation ecosystem of the university as an educational mechanism that takes into account different levels and needs for project-based learning. Mentoring, being one of the hallmarks of mentoring in project learning, is designed to ensure the continuous development of the learner's competencies throughout the entire educational/professional activity.

Design and interdisciplinarity are closely connected with one another, since in project training, not only knowledge in the field of modeling business processes, solving business problems are prioritized, but knowledge, skills and abilities acquired in interdisciplinary areas of professional activity are also important. It is design and interdisciplinarity that enhance the development of students' universal competencies that meet the needs of an innovative educational environment. The emphasis on mastering interdisciplinary competencies is determined by European network (ENAEE) [12], according to which graduates must have competencies that allow one:

- to think critically and solve environmental, economic, production and management problems, to understand their consequences for business and society;

- to build effective communication links;

- to develop innovative methods of analysis and problem solving;

- to communicate judgments that include reflections on relevant social and ethical issues.

\section{Conclusion}

Thus, the structural-competence approach as the basis of project-based learning at universities is not only associated with mastering universal competencies based on interdisciplinary knowledge, but, taking into account the needs of the business community, science, and the state, contributes to the transformation of professional competencies $[13,14]$.

Of course, the formation of a stable innovation ecosystem of the university is a new trend in the Russian educational environment, allowing students to be involved in research and project work at the university.

\section{References}

1. M.K. Habib, F. Nagata, K. Watanabe, Educ.Sci. 11, 46.

(2021)

https://doi.org/10.3390/educsci11020046

2. T. Konrad, A. Wiek, M. Barth, IJSHE International Journal of Sustainability in Higher Education 22 (3), (2021)

3. S.I.H. Liyanage, F.G. Netswera, Journal of the Knowledge Economy https://doi.org/10.1007/s13132-021-00769-y 
4. O.E. Malikh, I.K. Polyanskaya, M.E. Konovalova, O.Y. Kuzmina, O.V. Tarasyuk, I.V. Osipova, International Electronic Journal of Mathematics Education. 11(8) 3104-3113 (2016).

5. A. Cahyadi, R. Magda. Economies. 9(32) (2021) https://doi.org/doi:10.3390/economies9010032

6. K. Maaranen, H. Kynäslahti, Technology, Pedagogy and Education '(2021). DOI: 10.1080/1475939X.2021.1876756

7. M. Mielikäinen. Industry and Higher Education. (2021).

https://doi.org/10.1177/0950422221994471

8. R. Ravi, M.D. Janodia, Journal of the Knowledge Economy (2021). doi.org/10.1007/s13132-02100747-4

9. K.A. Siddiqui, M. Emad Al-Shaikh, I.A. Bajwa, A. Al-Subaie, Entrepreneurship and Sustainability Issues. 8(3), 267-279. (2021). http://doi.org/10.9770/jesi.2021.8.3(15)

10. Luigi T. De Luca, Propulsion physics (EDP Sciences, Les Ulis, 2009)

11. D.R Peskova, Yu.V. Khodkovskaya, V.S. Charikov, R.B. Sharafutdinov. GCPMED 2018. International Scientific Conference "Global Challenges and Prospects of the Modern Economic Development». 122, 1205-1212 (2019).

12. Bologna Declaration of 19 June 1999 (Wikisource: Documents of non-national or supranational organizations. Category: 1999 works)

13. The European Network for Accreditation of Engineering Education (ENAEE) Retrieved from: https://www.enaee.eu

14. N. Petch, Entrepreneur. (2016). Retrieved from: ttps://www.entrepreneur.com/article/271290

15. M. Lavčák, O. Hudec, Z. Sinčáková, Journal of the Knowledge, 1-19. (2019). 